110 Nordisk Råd
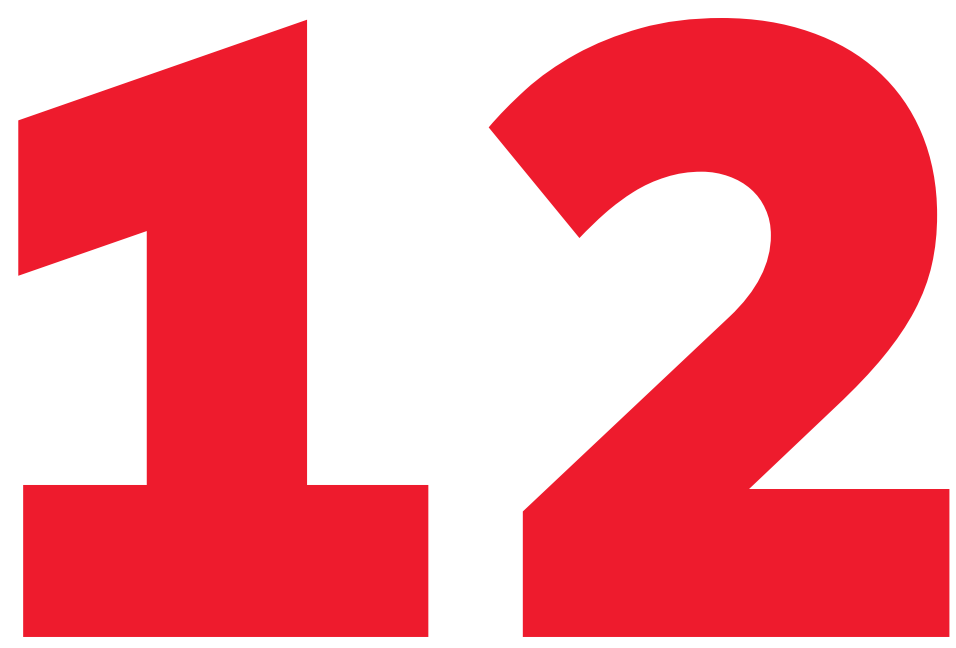

KONKRETE TILTAG

\title{
Norden i samlet kamp mod antimikrobiel resistens
}

En hvidbog indeholdende forslag til nye nordiske initiativer 
Norden i samlet kamp mod antimikrobiel resistens

En hvidbog indeholdende forslag til nye nordiske initiativer

ANP 2017:725

ISBN 978-92-893-4946-8 (PRINT)

ISBN 978-92-893-4947-5 (PDF)

ISBN 978-92-893-4948-2 (EPUB)

http://dx.doi.org/10.6027/ANP2017-725

(c) Nordisk Råd 2017

Layout: Louise M. Jeppesen

Tryk: Rosendahls

Printed in Denmark

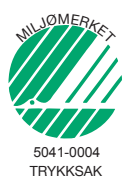

\section{Det nordiske samarbeidet}

Det nordiske samarbejde er en af verdens mest omfattende regionale samarbejdsformer.

Samarbejdet omfatter Danmark, Finland, Island, Norge og Sverige samt Færøerne,

Grønland og Åland.

Det nordiske samarbejde er både politisk, økonomisk og kulturelt forankret, og er en vigtig medspiller i det europæiske og internationale samarbejde. Det nordiske fællesskab arbejder for et stærkt Norden i et stærkt Europa.

Det nordiske samarbejde ønsker at styrke nordiske og regionale interesser og værdier i en global omverden. Fælles værdier landene imellem er med til at styrke Nordens position som en af verdens mest innovative og konkurrencedygtige regioner

\section{Nordisk Råd}

Ved Stranden 18

DK-1061 København K

www.norden.org

Download nordiske publikationer: www.norden.org/nordpub 


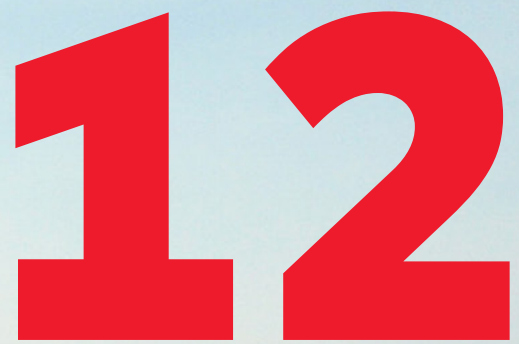

\section{KONKRETE TILTAG}

Norden i samlet kamp mod antimikrobiel resistens

En hvidbog indeholdende forslag til nye nordiske initiativer

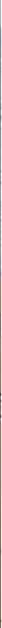




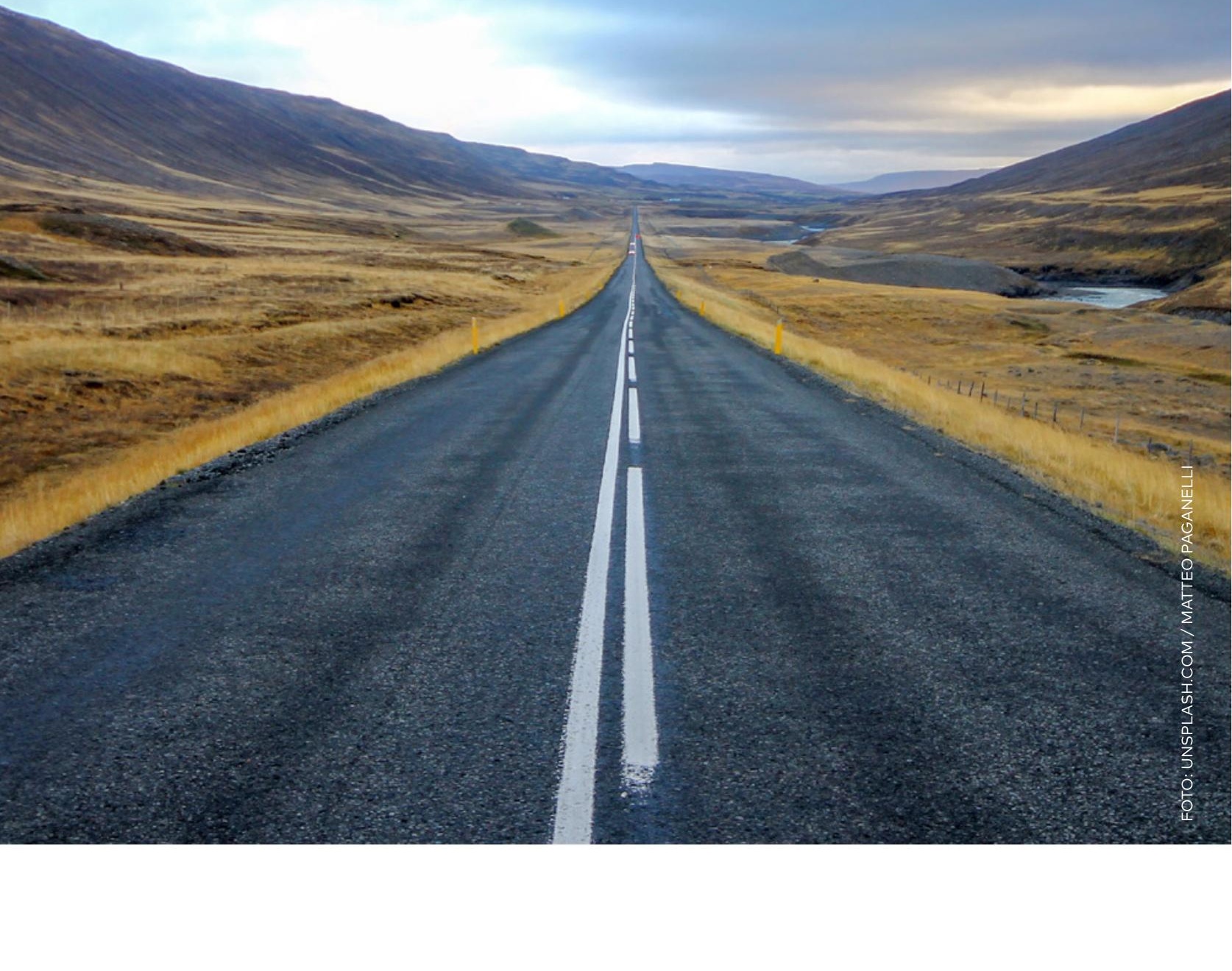




\section{INDHOLD}

INDLEDNING

Truslen fra antimikrobiel resistens og nødvendigheden af "One Health" 7

\section{BAGGRUND}

Den nordiske høring "Man dør vel ikke af lungebetændelse...?"

11

OVERORDNEDE MÅLSATNINGER

En 7-punktsstrategi

15

IMPLEMENTERING AF STRATEGI

12 konkrete tiltag

1. Hurtigere og mere præcis diagnostik

2. Optimal antibiotika behandling

3. Rationel og hensigtsmæssig brug af antibiotika

4. Forebyggelse af smittefare og spredning af behandlingskrævende infektioner
5. Anvendelse af vacciner inden for jordbrug, husdyrproduktion og akvakulturer

6. Incitamenter til udvikling af ny antibiotika og vacciner 29

7. Folkeoplysningskampagner i Norden

8. Fælles nordisk institut og online-database

9. Prioriteret liste over farlige patogener og fælles indkøb af særskilt vigtige antibiotika 36

10. Koordination af fødevarekontrol og arbejdsdeling mellem nationale myndigheder i Norden 39

11. Norden i Europa og resten af verden 40

12. Fælles nordisk plan

FORKORTELSER 42 


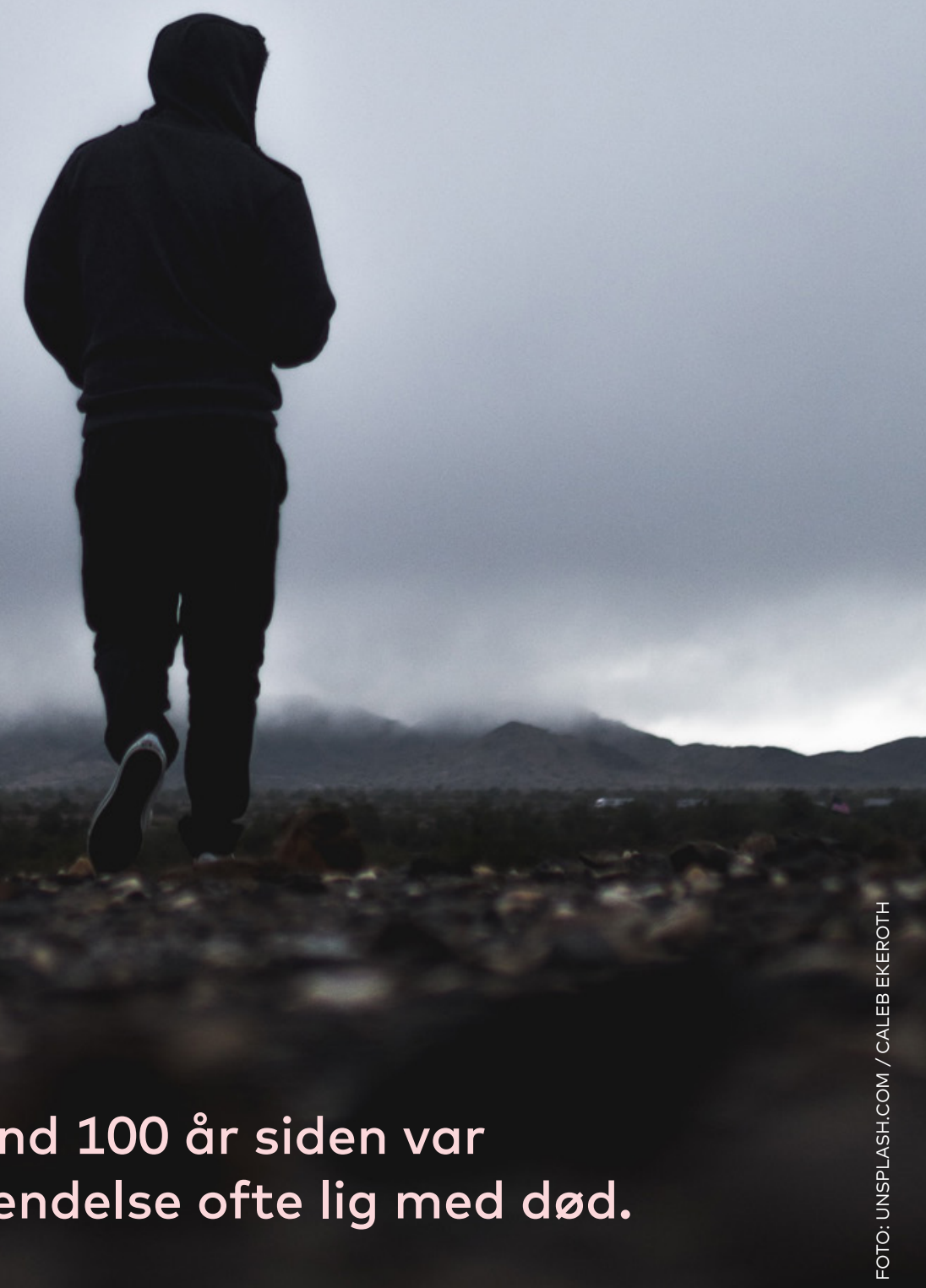

For mindre end 100 år siden var en lungebetændelse ofte lig med død. 


\section{INDLEDNING \\ Truslen fra antimikrobiel resistens og nødvendigheden of "One Health"}

For mindre end 100 år siden var en lungebetændelse ofte lig med død. Men lykkeligvis med opdagelsen af antibiotika blev de ellers dystre sygdomsudsigter ændret markant. Antibiotika er sidenhen blevet anvendt i mange forskellige sektorer - i alt lige fra sygdomsbehandling af mennesker til produktion af fødevarer.

I dag er antibiotika midler, man i mange sektorer tager for givet, vagtet om man som patient bliver behandlet for en lungebetændelse, eller man som landmand giver sin svinebesætning antibiotika for at slå diverse sygdomme ned. Sådan har det imidlertid ikke altid været.

En eskalerende og signifikant stigning i forbruget af antibiotika har imidlertid resulteret $i$, at hele verden i dag står overfor voksende udfordringer med resistente bakterier og mikrober indenfor mange forskellige områder. Hvis der ikke bliver truffet de rigtige politiske beslutninger $\mathrm{i}$ dag, kan det gå gruelig galt inden for de kommende årtier.
Allerede nu udgør antimikrobiel resistens (AMR), dvs. antibiotika- reststens, ${ }^{1}$ en stor trussel mod folke- sundheden verden over. Og proble- met vokser sig kun større med tiden. Ifølge Könbergrapporten, ${ }^{2}$ som blev udarbejdet i 2014 af den tidligere svenske sundheds- og socialminister, Bo Könberg, dør der i Europa årligt mindst 25.000 mennesker på grund af antibiotikaresistens, og i USA er tallet 23.000.

Udviklingen af nye antibiotika har længe været og er til stadighed stærkt begrænset. Og nye beregninger viser, at hvis situationen får lov til at fortsætte uhindret, vil det både

\footnotetext{
1 Antimikrobiel resistens er evnen af mikrober, såsom bakterier, vira, parasitter, eller svampe, til at vokse på trods af tilstedeværelsen af et kemisk stof som medicin og antibiotika, der normalt ville dræbe den, eller begrænse dens vækst.

2 Bo Könberg, "Det framtida nordiska hälsosamarbetet", http://dx.doi.org/10.6027/ANP2014-730, Nordiska Ministerrådet 2014.
} 
betyde en menneskelig og økonomisk katastrofe. Der er prognoser, som forudsiger, at multiresistente bakterier og mikrober i 2050 kan blive skyld i op til 10 mio. dødsfald på verdensplan (tallene inkluderer dog tuberkulose, HIV og malaria). Samtidig vil verdensøkonomien stå til et tab på op mod 100 billioner USD. ${ }^{3}$ Hvor slem udviklingen vil kunne tage sig ud i Norden og Europa er endnu uvist, men sikkert er det, at regionen ikke vil kunne værge sig mod spredningen af AMR og dens dødelige konsekvenser.

I forhold til problemet med AMR er det væsentlig at forstå, at sygdomme og sundhed hos mennesker og dyr er filtret ind i hinanden $i$ et fælles kredsløb og en fælles skæbne. Ca. $60 \%$ af alle infektiøse sygdomme hos mennesker stammer fra dyr ( $f x$ tuberkulose, rabies, fugleinfluenza og salmonella), og når det vedrører fremkomsten af nye sygdomme er tallet $75 \%$. Omvendt overføres også sygdomme og infektioner fra mennesker til dyr. Derfor skal dyrevelfærd, behandling med veterinærmedicin og menneskers sundhed ses i en sammenhæng.
På flere områder er det blevet tydeligt, at der er behov for, at læger, dyrlæger og andet fag-og sundhedspersonel arbejder sammen for at styrke sygdomsbekæmpelsen i hele kredsløbet - og ikke kun på enkelte adskilte punkter. På engelsk anvendes begrebet "One Health" til at beskrive denne form for sammentænkning af sundhedspolitiske strategier inden for det humane, veterinære og miljømæssige område.

"One Health" har været på Nordisk Råds dagsorden over længere tid og har været diskuteret på møder mellem Nordisk Råd (NR) og medlemmer af Europa-Parlamentet. "One Health" i forbindelse med antibiotikaresistens var også et hovedtema i den førnævnte Könbergrapport om nordisk sundhedssamarbejde, og emnet indgik tilmed i Danmarks formandskabsprogram for Nordisk Ministerråd (NMR) i 2015. Dette fulgte til en afsættelse af midler i Nordisk Ministerråds budget til opfølgning under 2016.

Af konkrete tiltag søsat for at fremme en nordisk "One Health"-politik og indsatsen mod AMR, vedtog

$3 \mathrm{Jim}$ O'Neil, Antimicrobial Resistance: Tackling a crisis for the health and wealth of nations, https://amr-review.org/sites/default/files/AMR\%20Review\%20Paper\%20-\%20Tackling\%20a\% 20 crisis\%20for\%20the\%20health\%20and\%20wealth\%20of\%20nations_1.pdf 
NMR i 2015 en "One Health"-deklaration mod antimikrobiel resistens. ${ }^{4}$ Desuden blev der også nedsat en nordisk ekspertgruppe i 2013 og en strategigruppe i 2015 på området.

Strategigruppen har mandat til "at anvende det nordiske samarbejde for at støtte det internationale koordinerende arbejde som foregår $\mathrm{i} E \mathrm{E}$, WHO, FAO, OIE og støtte det fælles nordiske arbejde om antimikrobiel resistens". Endvidere skal gruppen "fungere som bindeled mellem det faglige og det politiske niveau i de nordiske lande og dermed fastholde et politisk fokus på antibiotikaresistens".

Siden dens oprettelse har strategigruppen endnu ikke haft chancen for at forelægge et egentligt udspil til, hvordan et eventuelt fælles nordisk samarbejde kunne udformes, og hvilke indsatsområder der burde fokuseres på i Norden inden for den nærmeste fremtid. Derfor er nærværende hvidbog det første bud på, hvilke politiske tiltag og konkrete løsningsforslag det anbefales, at de nordiske lande sammen bør efterstræbe i bekæmpelsen af AMR.
Ud fra de mange anbefalinger, som fremkom under høringen "Man dør vel ikke af lungebetændelse...?", præsenteres $\mathrm{i}$ indeværende dokument en håndfuld rekommandationer, som det vurderes med fordel kan gennemføres og give merværdi gennem et styrket nordisk samarbejde. Forhåbningen er, at hvidbogen vil kunne danne grundlaget for en mere aktiv nordisk samarbejdspolitik, i såvel NR og NMR som i andre relevante tværgående og internationale fora.

Til sidst, og ikke mindst, er det desuden forventningen, at hvidbogens rekommandationer vil kunne anvendes som en del af NMR-strategigruppens fortsatte og vigtige arbejde.

4 Deklarationen blev vedtaget af de nordiske sundhedsministre og fødevare- og landbrugsministre, se http:// www.norden.org/da/nordisk-ministerraad/ministerraad/nordisk-ministerraad-for-social-og-helsepolitik-mr-s/ deklarationer-og-erklaeringer/declaration-on-antimicrobial-resistance-through-a-one-health-perspective 


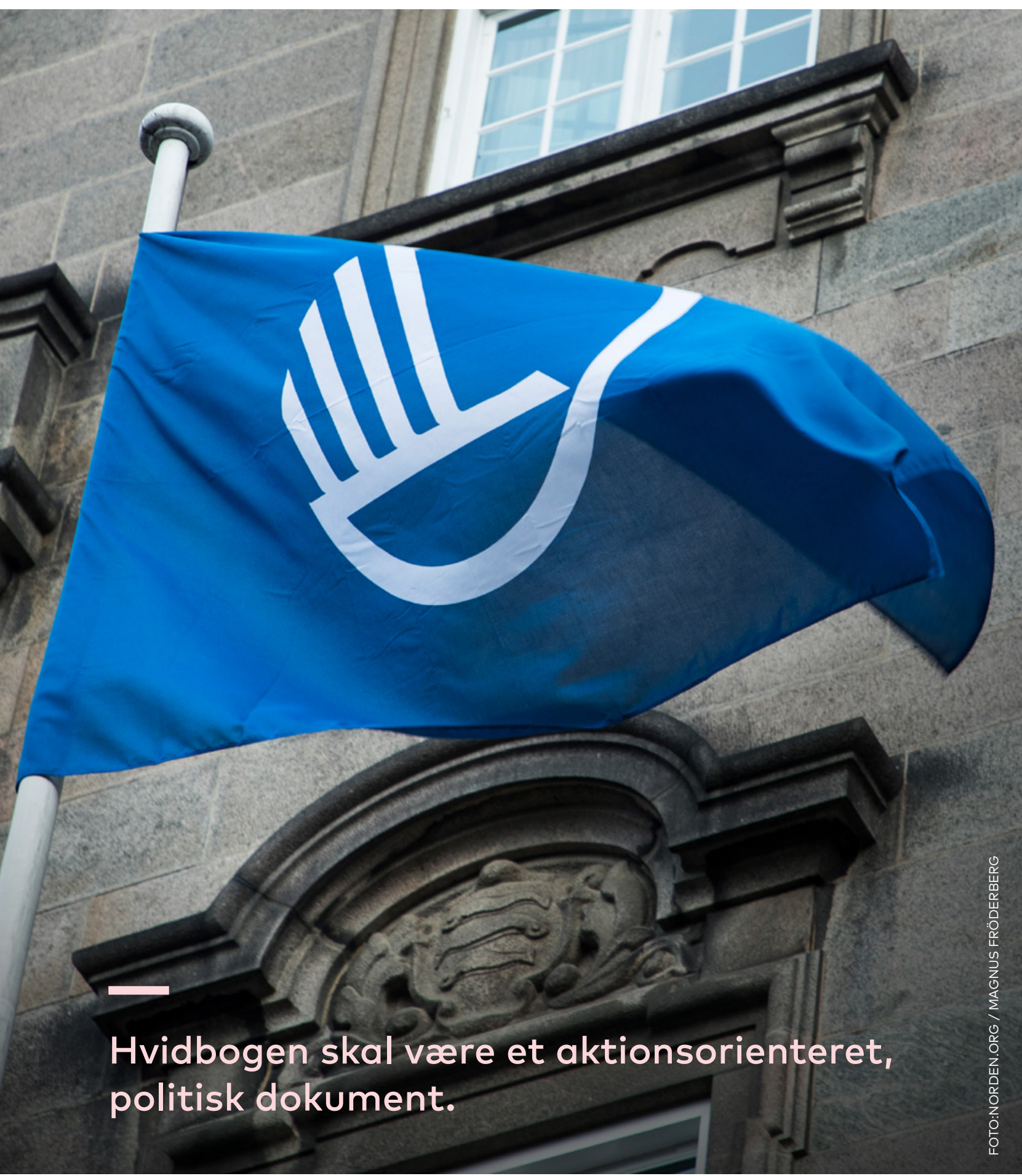




\section{BAGGRUND \\ Den nordiske høring "Man dør vel ikke af lungebetændelse...?"}

Nærværende dokument er den endelige opsamling på høringen "Man dør vel ikke af lungebetændelse...?", som blev afholdt den 6. december 2016, på Christiansborg i København, på opfordring af det danske formandskab for Nordisk Råds Præsidium og rådets præsident, Henrik Dam Kristensen. Under høringen deltog tilmeldte fra alle de fem nordiske lande og de relevante fagmiljøer.

Overordnet var intentionen med høringen at sætte fokus på fænomenet antimikrobiel resistens (AMR), der i dag udgør en stadig voksende trussel mod folkesundheden over hele verden. Men derudover havde man også to yderligere formål med høringen.

For det første var hensigten, at denne skulle være en kærkommen lejlighed til at indsamle både erfaringer og gode råd fra alle de nordiske lande til, hvordan man i Norden som region kan være med til at håndtere samt bekæmpe AMR og dens udbre- delse, såvel internt regionalt som internationalt.

For det andet - og endnu vigtigere - var det desuden fra formandskabets og præsidentens side et absolut kriterium for afholdelse af høringen, at de indsamlede råd og erfaringer, som blev præsenteret, efterfølgende skulle sammenfattes til en hvidbog, der fremadrettet kunne bruges som grundlag og udgangspunkt for enten en fælles nordisk aktion eller en langsigtet politisk handlingsplan.

Kortfattet lød kravet, at hvidbogen ikke blot skulle beskrive truslen, som AMR udgør, men også formulere 1) hvordan problemet potentielt kan løses med eksisterende og nye virkemidler, 2) hvilke aktører skal medvirke i løsningen, og 3) hvilken rolle Norden kan spille i en bred global aktion mod AMR.

Hvidbogen skulle med andre ord være et aktionsorienteret, politisk dokument. 


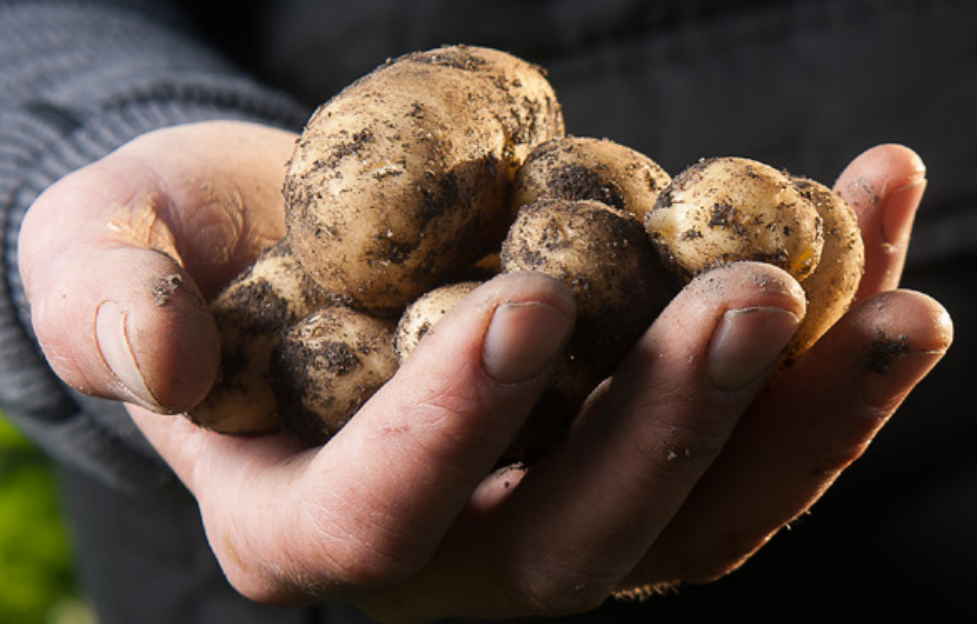


For at løse den udstukne opgave bedst muligt blev en række forskellige nordiske fagfolk, forskere, eksperter og embedsmænd og -kvinder m.fl. fra henholdsvis sundhedsog hospitalssektoren, landbrugsog veterinærsektoren og medicinalindustrien inviteret til at deltage i høringen den 6. december på Christiansborg. Her blev de bedt om at give deres bud på, hvordan man $\mathrm{i}$ Norden på bedst mulig vis kan tackle de store udfordringer et uhensigtsmæssigt brug af antibiotika har ført til og vil føre til i fremtiden. Og det på tværs af forskellige sektorer i regi af One Health-tankegangen.

Blandt de deltagende oplægsholdere var: Dr. Joseph Larsen (US), deputy director of the Biomedical Advanced Research and Development Authority (BARDA) og bestyrelsesmedlem for Carb-X. Niels Frimodt-Møller (DK), professor og klinikchef for Klinisk Mikrobiologisk Afdeling, Rigshospitalet samt medlem af Det Nationale Antibiotikaråd og leder af DANCARD. Dag Berild (N), MD, PhD, professor i Infectious Diseases, Oslo
University Hospital. Sophie Noya (B), director public policy, MSD Europa \& Canada. Johan Struwe (S), speciallæge ved Enheten för Antibiotika och Vårdhygien, Folkhälsmyndigheten. Søren Brostrøm (DK), direktør i Sundhedsstyrelsen. Frank Aarestrup (DK), professor ved DTU og en af ophavsmændene til overvågningsprogrammet DANMAP. Jan Dahl (DK), dyrlæge og chefkonsulent ved Landbrug \& Fødevarer. Carsten Jensen (DK), formand for Den Danske Dyrelægeforening. Solfrid Åmdal $(N)$, seniorrådgiver i Seksjonen for Landdyrhelse, Matttilsynet. Elisabet Lindal (S), seniorrådgiver i Enheten för Internationella Frågor och Djurhälsopersonal, Jordbruksverket. $^{5}$

De løsningsforslag og tiltag, der fremstilles $i$ indeværende hvidbog, baserer sig i vid udstrækning på de pointer, som oplægsholderne fremlagde i deres præsentationer under høringen den 6. december 2016. Dokumentet er udarbejdet af Nordisk Råds sekretariat ved Simon Langkjær.

5 Programmet findes her: http://www.norden.org/da/nordisk-raad/sessioner-og-moeder/moeder/ alle-moeder-i-nordisk-raad-oprettes-i-denne-mappe/man-doer-da-vel-ikke-af-lungebetaendelseen-nordisk-hoering/ 


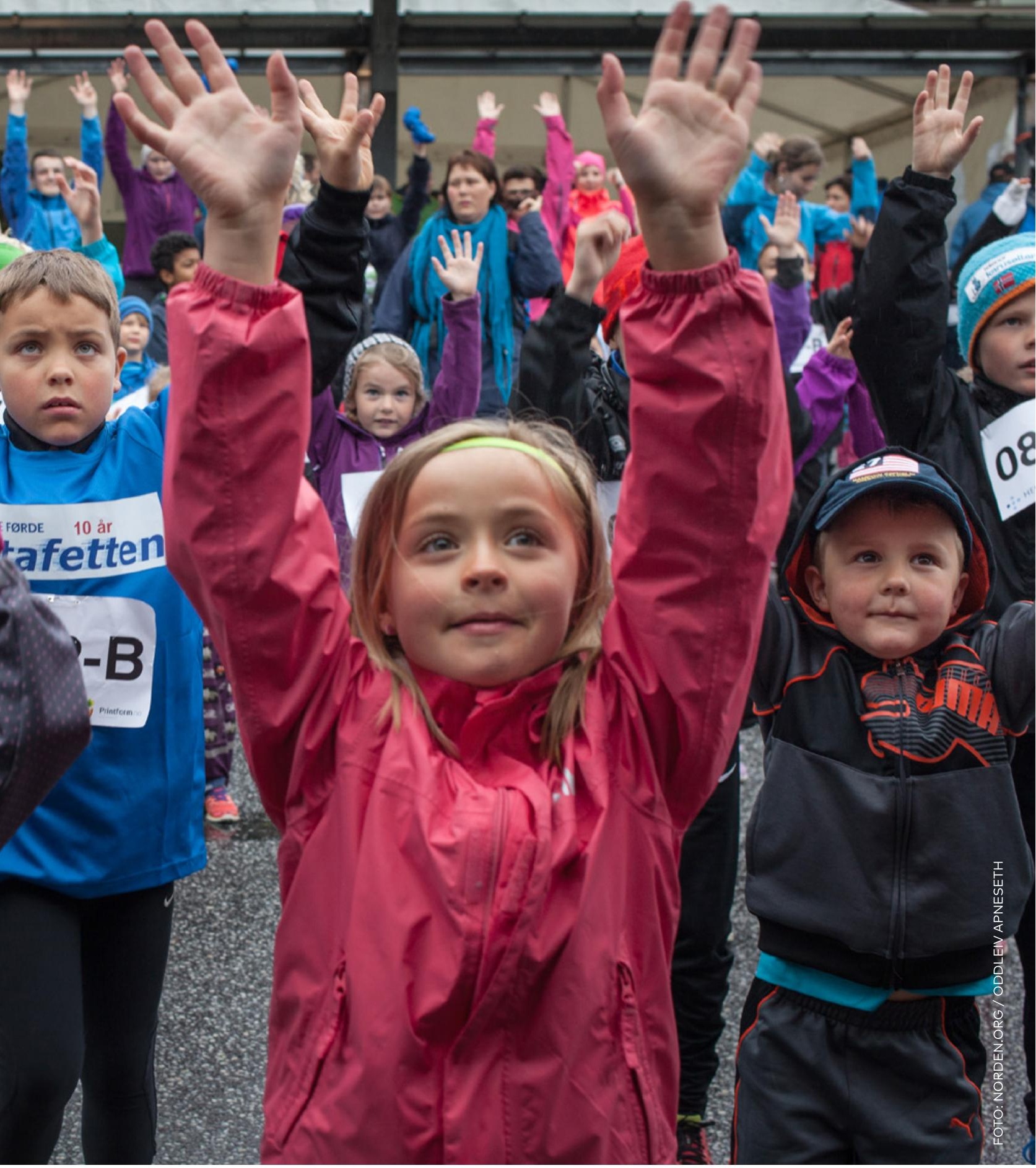




\section{OVERORDNEDE MÅLSAETNINGER En 7-punktsstrategi}

Målet med den nordiske høring "Man dør vel ikke af lungebetændelse...?" var som udgangspunkt at adressere den trussel, som antibiotikaresistens udgør mod fremtidens sundhed både lokalt, regionalt og internationalt, samt at udpege og formulere en række prioriterede handlingsforslag og -initiativer til, hvordan de nordiske lande kan komme truslen til livs.

I Norden er der igennem de sidste år sat et øget fokus på resistensproblematikken gennem One Health-initiativet. Men bakterier og mikrober er grænseløse og i konstant udvikling, og deres voksende resistens mod antibiotika er en trussel, der kræver nye og mere dynamiske tiltag for at hindre tilstande, hvor en simpel operation foregår med livet som indsats, en lungebetændelse bliver dødelig, og infektioner spreder sig som epidemier fra dyr til mennesker.
Antibiotikaresistens kan som sådan ikke håndteres ud fra en silo-tankegang. Der er behov for, at alle relevante sektorer fra sundhed, forskning og industri til veterinær, landbrug og miljø involveres i en koordineret indsats. Samtidig kalder problemets omfang på målrettet politisk handling. Derfor vil en langsigtet strategisk plan, som inkluderer alle de nordiske lande, også være et oplagt svar på situationen.

En sådan fælles nordisk strategiplan kunne eksempelvis tage form som det nyligt etablerede samarbejde Carb-X, hvor USA's og Storbritanniens sundhedsmyndigheder er gået sammen i kampen mod antibiotikaresistens og har samlet regeringerne, de akademiske miljøer og industrien på tværs af Atlanten. ${ }^{6}$

Uanset dens præcise udformning, er det en absolut forudsætning, at en

\footnotetext{
6 Med afsæt i Obama-administrationens "National Action Plan for Combating Antibiotic-Resistant Bacteria" og den engelske rapport "Tackling Drug-resistant Infections Globally".
} 
eventuel regional strategi for Norden baserer sig på nogle helt overordnede målsætninger, hvorudfra konkrete praktiske, lovgivningsmæssige og administrative løsningsmodeller sidenhen kan konstrueres og modificeres.

På baggrund af de anbefalinger, som blev præsenteret af oplægsholderne under høringen den 6. december 2016, kan de overordnede målsætninger for en nordisk strategi opsummeres til følgende punkter:

1. Reduktion af behovet for antibiotikabehandling gennem vaccination og forebyggelse af smittefare.

2. Rationalisering af anvendelsen af antibiotika til behandling af mennesker og dyr.

3. Indsamling af viden om spredningsmønstre for og udbredelse af antimikrobiel resistens.

4. Indsamling af viden om optimal anvendelse af allerede eksisterende antibiotika og vacciner.
5. Sikring af incitamenter til udvikling af ny sundhedsteknologi, innovativ medicin og vacciner.

6. Styrkelse af udbredelse og vidensdeling af "best practices".

7. Politisk pres og dialog gennem internationalt samarbejde.

Det vigtige spørgsmål bliver dog selvfølgelig bagefter, hvordan målsætningerne rent faktisk kan implementeres og efterleves $i$ praksis.

For at svare på dette spørgsmål, oplistes i resten af denne hvidbog 12 stærkt kvalificerede og fagligt funderede rekommandationer, som viser, hvordan det er muligt oversætte de ovenstående målsætninger til mere håndfaste tiltag.

Den overordnede pointe, som kan drages på baggrund af tiltagene, er, at en samlet indsats fra de nordiske lande i bekæmpelsen af AMR ikke kun vil være ressourcesparende, men også effektiviserende og befordrende for et bedre værn imod sundhedsfaren. 
Overordnede målsætninger for en nordisk strategi opsummeres til følgende punkter:

1. Reduktion af behovet for antibiotikabehandling gennem vaccination og forebyggelse af smittefare.

2. Rationalisering af anvendelsen af antibiotika til behandling af mennesker og dyr.

3. Indsamling af viden om spredningsmønstre for og udbredelse af antimikrobiel resistens.

4. Indsamling af viden om optimal anvendelse af allerede eksisterende antibiotika og vacciner.

5. Sikring af incitamenter til udvikling af ny sundhedsteknologi, innovativ medicin og vacciner.

6. Styrkelse af udbredelse og vidensdeling af "best practices".

7. Politisk pres og dialog gennem internationalt samarbejde. 


\section{IMPLEMENTERING AF STRATEGI 12 konkrete tiltag}

\section{Hurtigere og mere præcis diagnostik}

Der er behov for en lancering og finansiering af fælles nordiske udviklings- og innovationsprogrammer, der kan sikre udviklingen af nye og mere effektive metoder til hurtigere diagnostik af infektioner, sådan at patienter kan modtage den rette behandling, når dette er nødvendigt.

En sikring og udvikling af bedre og hurtigere diagnostiske metoder for læger såvel som dyrlæger vil være et væsentligt skridt mod en mere generel nedsættelse of antibiotikaforbruget inden for såvel den humane som den veterinære sundhedsbehandling. Det følger nemlig, at bedre muligheder for en hurtig diagnostik vil give et oplyst grundlag for lægerne til at behandle hensigtsmæssigt ud fra. Derudover vil en hurtigere diagnostik desuden mindske risikoen for fejlbehandling, da det vil betyde, at kun bakteriesmittede - og ikke virussmittede - individer vil modtage en antibiotikabehandling. Hurtigere og bedre diagnostiske redskaber vil desuden nedsætte behovet for profylaktisk medicinering samt flokmedicinering inden for landbruget.

De nordiske lande har tidligere haft mange og gode erfaringer med at samle ressourcer i forskellige udviklings- og innovationsprogrammer, og der findes nordiske institutioner med erfaring i den slags virksomhed, fx Nordic Innovation. 


\section{Optimal antibiotikabehandling}

Det anbefales, at der lanceres og finansieres kliniske undersøgelser med henblik på at determinere den optimale behandling med antibiotika, samt at der udfærdiges fælles nordiske retningslinjer herfor.

Både indenfor det human- og veterinærmedicinske område eksisterer der for øjeblikket et vældigt behov for et styrket og stærkt øget fokus på klinisk forskning, der kan undersøge den optimale anvendelse af antibiotika. Det handler både om den rette dosering af de forskellige antibiotikatyper samt den ideelle behandlingstid for specifikke antibiotikabehandlinger.

Behovet er især stort, når det gælder viden om den optimale anvendelse af ældre generationer af antibiotika. Inden for både det human- og veterinærmedicinske område er der over de seneste mange år kun blevet udført ganske få undersøgelser, som har beskæftiget sig med pencillins og ældre antibiotika-generationers virkning i forhold til bredspektret og nyere antibiotika. Denne lakune i forskningen skyldes især en mangel på støtte og økonomiske incitamenter, hvilket uundgåeligt har resulteret $\mathrm{i}$ en aftagende interesse hos medicinalindustrien og dårligere retningslinjer for behandlinger.

Enkelte undersøgelser er dog blevet udført, når det gælder behandlingen af mennesker. Og disse har bl.a. afsløret, at den anbefalede behandlingstid for diverse antibiotikabehandlinger i flere tilfælde enten er for lang eller langt overskrider punktet for optimal effekt. 
Et eksempel er streptokok-halsinfektion, som i Norge har en anbefalet behandlingstid på 5-10 dage med antibiotika. Undersøgelser har imidlertid vist, at den optimale behandlingstid faktisk ligger i spændet mellem 3-5 dage. Et andet eksempel kunne også være cystitis, dvs. blærebetændelse, som i flere lande har en behandlingstid varierende fra 3-7 dage med antibiotika. Seneste undersøgelser har dog vist, at behandling af cystitis muligvis kan suppleres med ordinering af ibuprofen, der er et smertelindrende og anti-inflammatorisk lægemiddel, hvilket vil nedsætte det samlede indtag af antibiotika. Et tredje eksempel på en optimering af antibiotikabehandling er, at man i Sverige med STRAMA-finansierende studier har påvist, at nyreinfektion (pyelonefritis) hos kvinder kun behøves behandlet i en fremfor to uger.
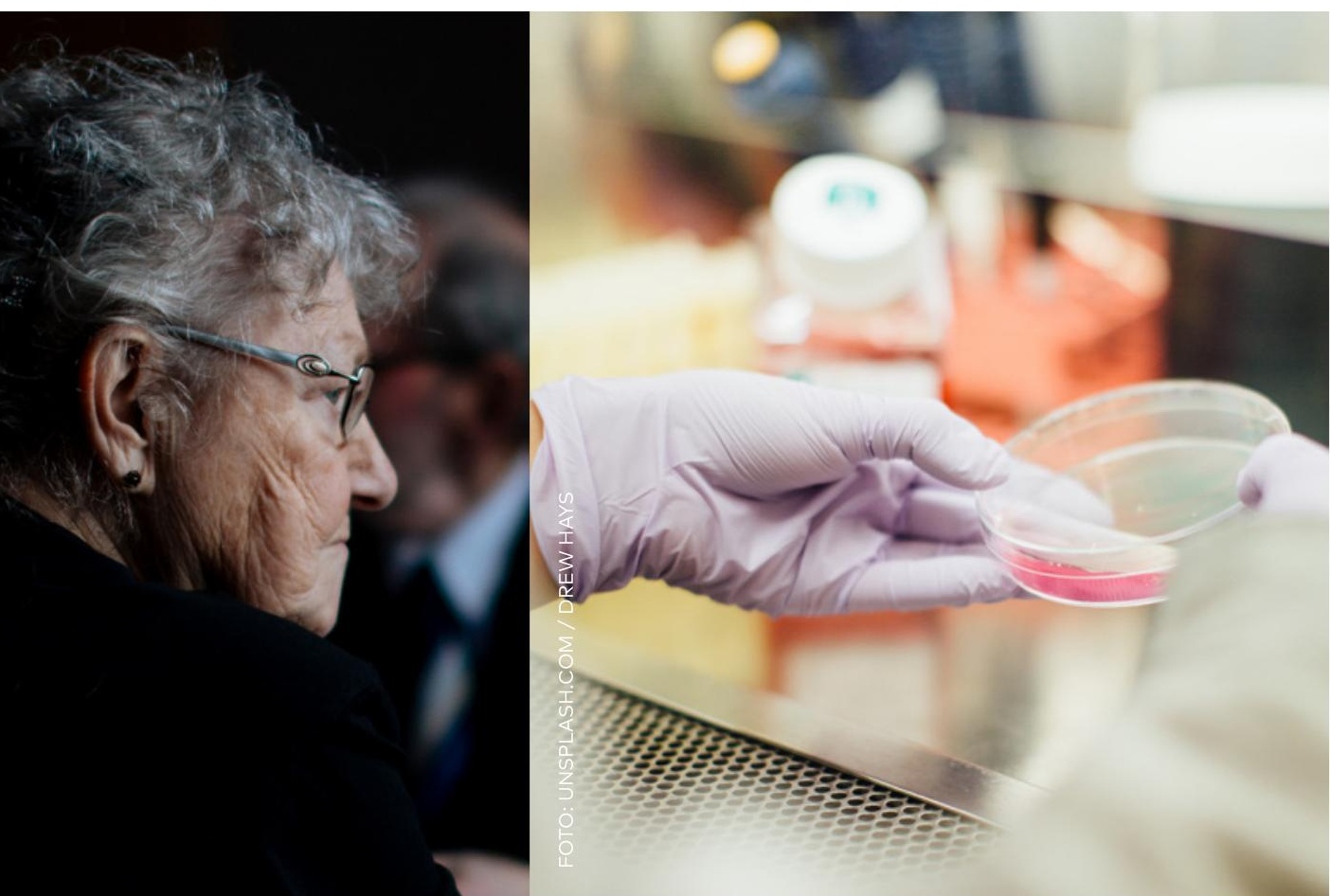


\section{Rationel og hensigtsmæssig brug af antibiotika}

Der findes et behov for udviklingen af fælles nordske retningslinjer og incitamenter, som fremmer en mere rationel og hensigtsmæssig brug af antibiotika, kombineret med en mere opdateret rådgivning, der bygger på de seneste indsamlede data i de nordiske lande.

Langt den største andel af antibiotikarecepter, der udskrives i de nordiske lande, bliver ikke udskrevet på sygehusene eller dyreklinikkerne, men i det primære sundhedssystem - dvs. ude blandt de almindelige praktiserende læger og dyrlæger. I Danmark udgør udstedelsen af antibiotika til mennesker uden for det sekundære sundhedssystem ca. $90 \%$. Netop derfor bør de praktiserende læger, tandlæger og dyrlæger på de lokale klinikker også være i stærkt fokus, hvis man ønsker en mere rationel anvendelse af antibiotika.

Med en "rationel" anvendelse af antibiotika menes der "motiveret", "nyttig" og "tilsigtet". Praktiserende læger, tandlæger og dyrelæger skal generelt blive bedre til i individuelle situationer at vurdere og skønne, hvorvidt behandling med antibiotika faktisk vil have den tilsigtede virkning, som både lægen og patienten i samråd ønsker, eller ej. Målet med en rationalisering af behandling med antibiotika er med andre ord at forbedre lægens og dyrlægens dømmekraft og vedkommendes grundlag for at kunne afgøre, hvorvidt en eventuel receptbehandling er velmotiveret, nødvendig og givtig.

Et eksempel på rationalisering af behandlingen med antibiotika ses i Norge, hvor det er blevet vedtaget, at norske læger skal skrive en diagnosekode på deres antibiotikarecepter, fordi der er for stor variation i udskrivelsen af antibiotika for de samme infektioner mellem de praktiserende læger. Dette lagres i en national recept-database, hvor lægerne kan sammenligne deres recept med 
gennemsnittet. På den måde håber man at bidrage til en mere rationel brug af antibiotika.

Et andet alternativ er STRAMA-programmet i Sverige, med hvilket man har påvist, at en målrettet politisk indsats for en mere rationel antibiotikabehandling kan medvirke til en væsentlig reduktion af det generelle forbrug af antibiotika blandt mennesker, uden at dødeligheden stiger. Programmet involverede bl.a. fremsættelsen af specifikke mål på landsplan, der handlede om rationel brug af receptbehandlinger, mere restriktive retningslinjer for udskrivelsen af receptmedicin samt en bedre national og interregional rådgivning af praktiserende læger om den seneste anbefalede behandling med antibiotika.

En lignende politik kunne med fordel oversættes til det veterinære område, landbruget og produktionen af fødevarer.

I forhold til Sverige er udskrivelsen af antibiotikarecepter til børn under 4 år fx dobbelt så høj i Danmark. Dette tal kunne imidlertid nedbringes, såfremt der blev indført fælles nordiske retningslinjer i stil med de svenske.

Fx kunne man indføre såkaldte "vent-og-se-recepter", et forbud mod udstedelse af recepter over telefonen, kommunale farmaceuter, lokale "STRAMA-grupper", computerprogrammer med forslag til behandling ud fra indikation, osv. ${ }^{7}$

\footnotetext{
7 Til orientering står der beskrevet i den danske "Vejledning om ordination af antibiotika" fra 2012, at der bør udvises større forsigtighed vedrørende brug af antibiotika. Vejledningens mål er, at indikationerne for, hvornår der bruges antibiotika, strammes i en mere rationel retning, og at der anvendes præparater, der sjældnere giver anledning til resistensudvikling, herunder specielt at målrette brugen af carbapenemer, fluorokinoloner og cephalosporiner. Vejledningen er relativt grundig og involverer både privatpraktiserende læger, hospitaler og også aspektet omkring inkludering af viden om AMR i fx lærebøger. Vejledningen kan ses i sin helhed på følgende link: https://www.retsinformation.dk/Forms/R0710.aspx?id=157975
} 


\section{Forebyggelse af smittefare og spredning af behandlingskrævende infektioner}

Det anbefales, at der lanceres og finansieres fælles nordiske undersøgelser, retningslinjer og initiativer, som skal være med til at forebygge dannelsen og spredningen af behandlingskrævende infektioner hos mennesker og dyr. Sådanne tiltag bør inkludere lancering af vaccinationsprogrammer, specifikke bekæmpelsesprogrammer for infektioner hos husdyr, indskærpelse af krav til hygiejnen på bedrifter såvel som behandlingsklinikker og vidensdeling og oplysning om god sundhedspleje og dyrepleje.

Når det specifikt kommer til landbruget og husdyrproduktionen, vil et vigtigt skridt mod en reduktion af antibiotikabehovet desuden være at undersøge, hvordan alternative og forskellige former for dyrehold og bedrifts-

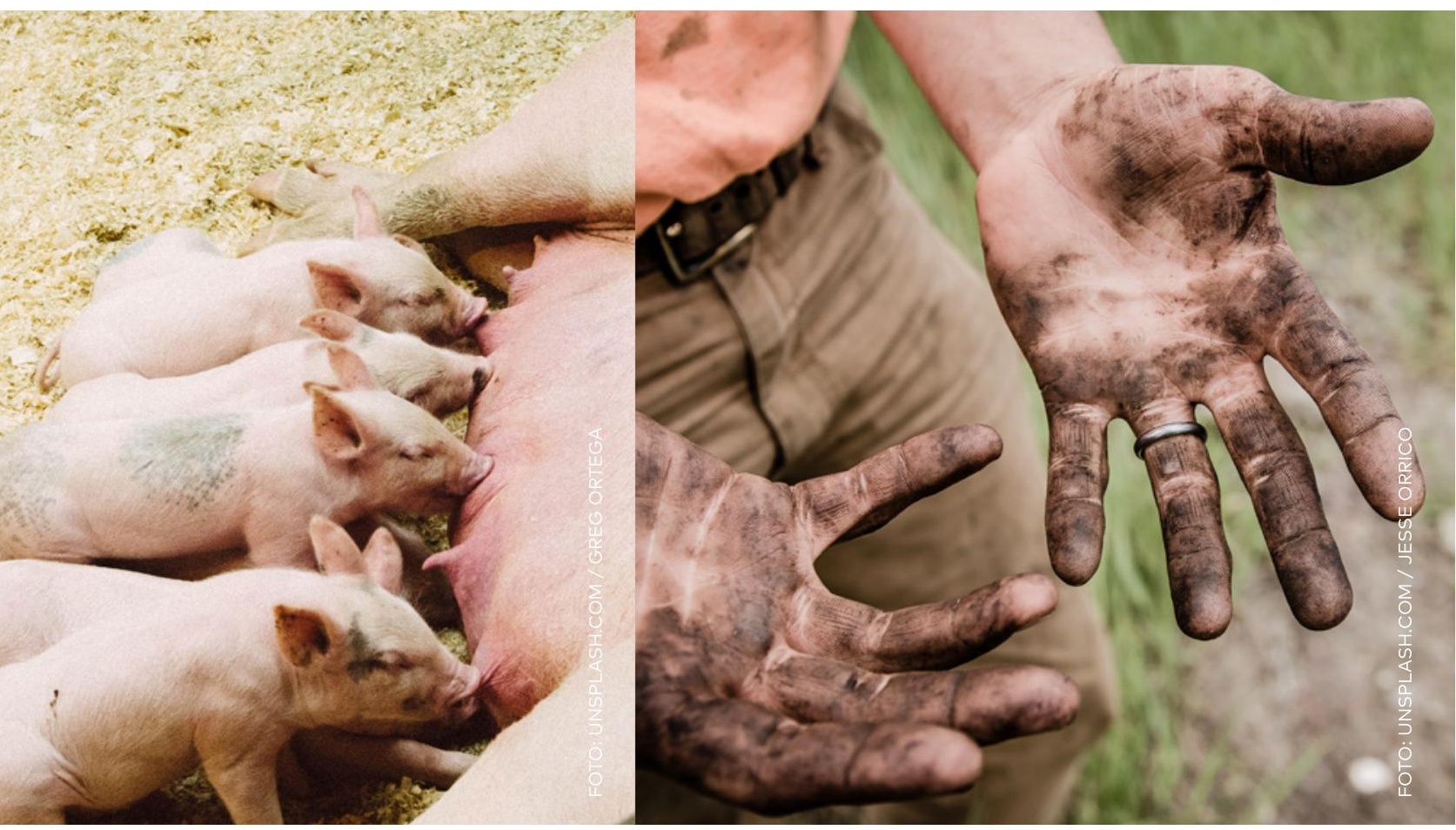


forhold kan have en forebyggende og reducerende effekt på anvendelsen og forbruget af antibiotika.

Med de seneste årtiers koncentration af fødevareproduktion opstår nye risici for, at der sker spredning af smitsomme sygdomme til et meget stort antal dyr. Omvendt er der også i disse moderne industrialiserede produktioner helt andre muligheder for at styre sundheden ved forskellige hygiejne-, management- og forebyggelsesstrategier. Nordiske, nationale og lokale smittebeskyttelsesplaner, overordnede sundhedsprogrammer og hygiejneprogrammer kan i stor udstrækning begrænse risikoen for introduktion af smitstoffer og bør understøttes og videreudvikles.

I den forbindelse kunne der fx søges inspiration fra Norge og Sverige, hvor man i de seneste år fra statens og erhvervslivets side har haft stigende politisk fokus på smitteforbyggende tiltag samt en forbedring af hygiejneforholdene og hygiejnekontrollen ude blandt landets landbrugsbedrifter under overskriften "Friske dyr behøver ikke medicin".

I Sverige har man tilmed indført lovgivning, hvilket har betydet, at de almengældende krav til dyreejernes og bedrifternes hygiejneforanstaltninger er blevet skærpet. Samtidig har man indført generelt højere krav til hygiejne- og infektionskontrol inden for den veterinære sundhedspleje, end man havde tidligere. ${ }^{8}$ Desuden findes der i Sverige et nationalt program for smittefare og hygiejne. I Danmark er smittebeskyttelsesplaner en integreret del af den veterinære rådgivning.

8 Der findes i Sverige et nationalt program for smittefare og hygiejne, se www.smittsäkra.se 


\section{Anvendelse af vacciner inden for jordbrug, husdyrproduktion og akvakulturer}

Det anbefales, at der etableres og finansieres fælles nordiske forskningsprogrammer, som skal undersøge og dokumentere den forebyggende effekt, som vacciner og vaccinationsprogrammer kan have på sundheden hos jordbrug, produktionsdyr og akvakultur og anvendelsen af antibiotika mod infektioner. Dette gælder både eksisterende og potentielt nye vacciner.

Det er alment anerkendt, at udviklingen og brugen af vacciner til bekæmpelsen af specifikke patogener og infektionssygdomme potentielt vil kunne have en forebyggende effekt på anvendelsen af antibiotika inden for såvel landbruget som dyrkelsen af akvakulturer. Vaccinen udløser dannelsen af særlige antistoffer, som inaktiverer eller begrænser bakterier og vira og deres skadelige og sygdomsfremkaldende effekt og øger således den generelle modstandskraft i produktionsdyr og akvakulturer, med mindsket behov for antibiotika som en naturlig konsekvens.

I Norge er man verdensledende på området. Og især når det gælder norsk akvakultur, er der blevet gjort en stor national indsats, som har reduceret forbruget og anvendelsen af antibiotika betragteligt. Men selvom der i Norge bliver udført megen kvalificeret forskning, har der generelt i Norden imidlertid ikke været tilstrækkelig støtte, offentlig interesse eller tilstrækkelig tilførsel af midler til udviklingen af vacciner til anvendelse inden for landbrug og akvakulturer, hvorfor det bør være en væsentlig prioritet for en samlet nordisk indsats. 
En udvikling af flere og bedre vacciner vil betyde, at anvendelsen af antibiotika i forbindelse med behandlingen af udbredte bakterier og ofte forekommende infektioner i fremtiden kunne blive nødløsningen frem for hovedløsningen. I de tilfælde, hvor udvindelse og anvendelse af vaccine ikke vil være mulig, anbefales det, at man i stedet opretter kontrolprogrammer, som skal minimere og inddæmme spredningen af disse sygdomme, således at behovet for behandling med antibiotika også minimeres.

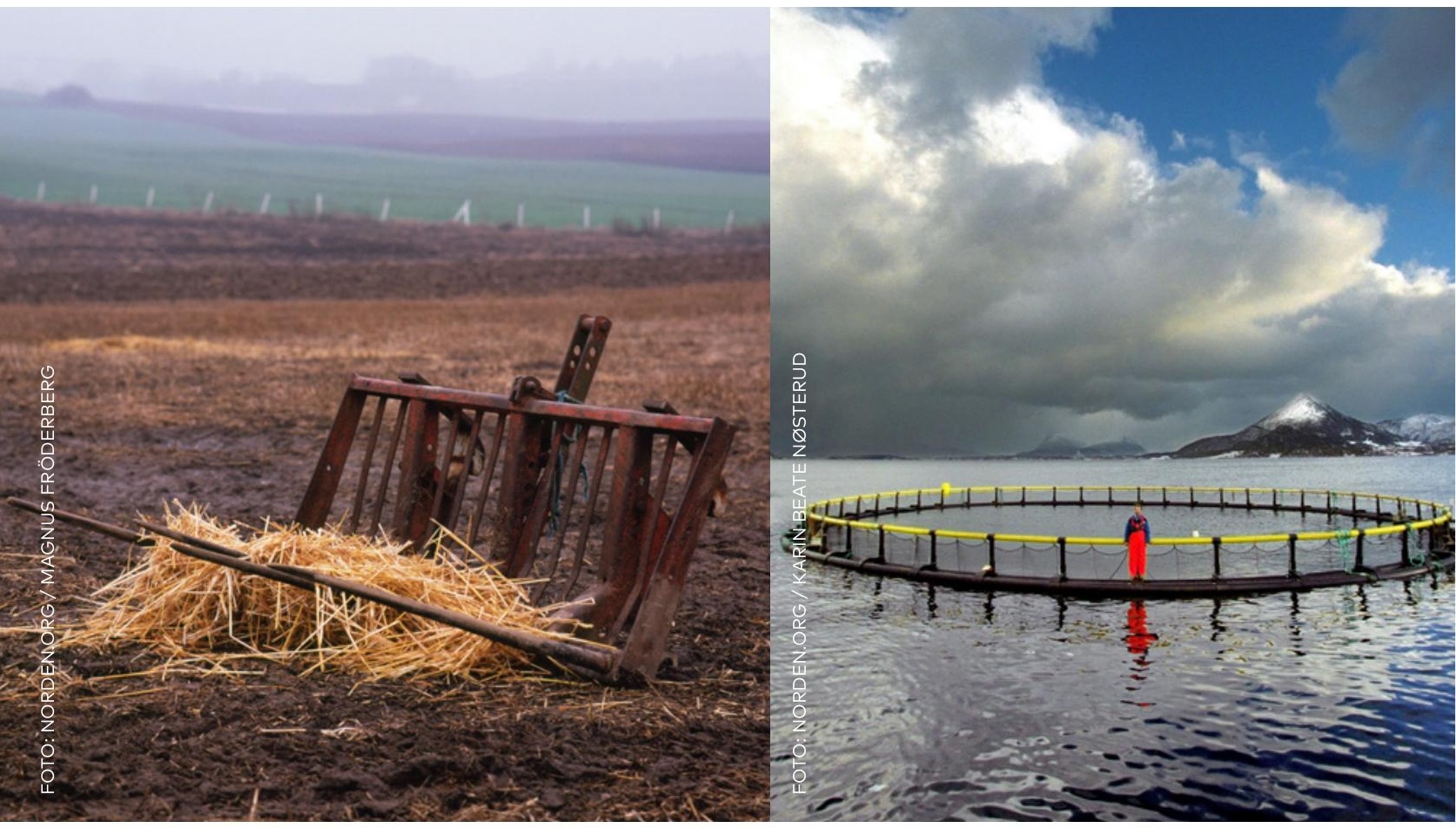




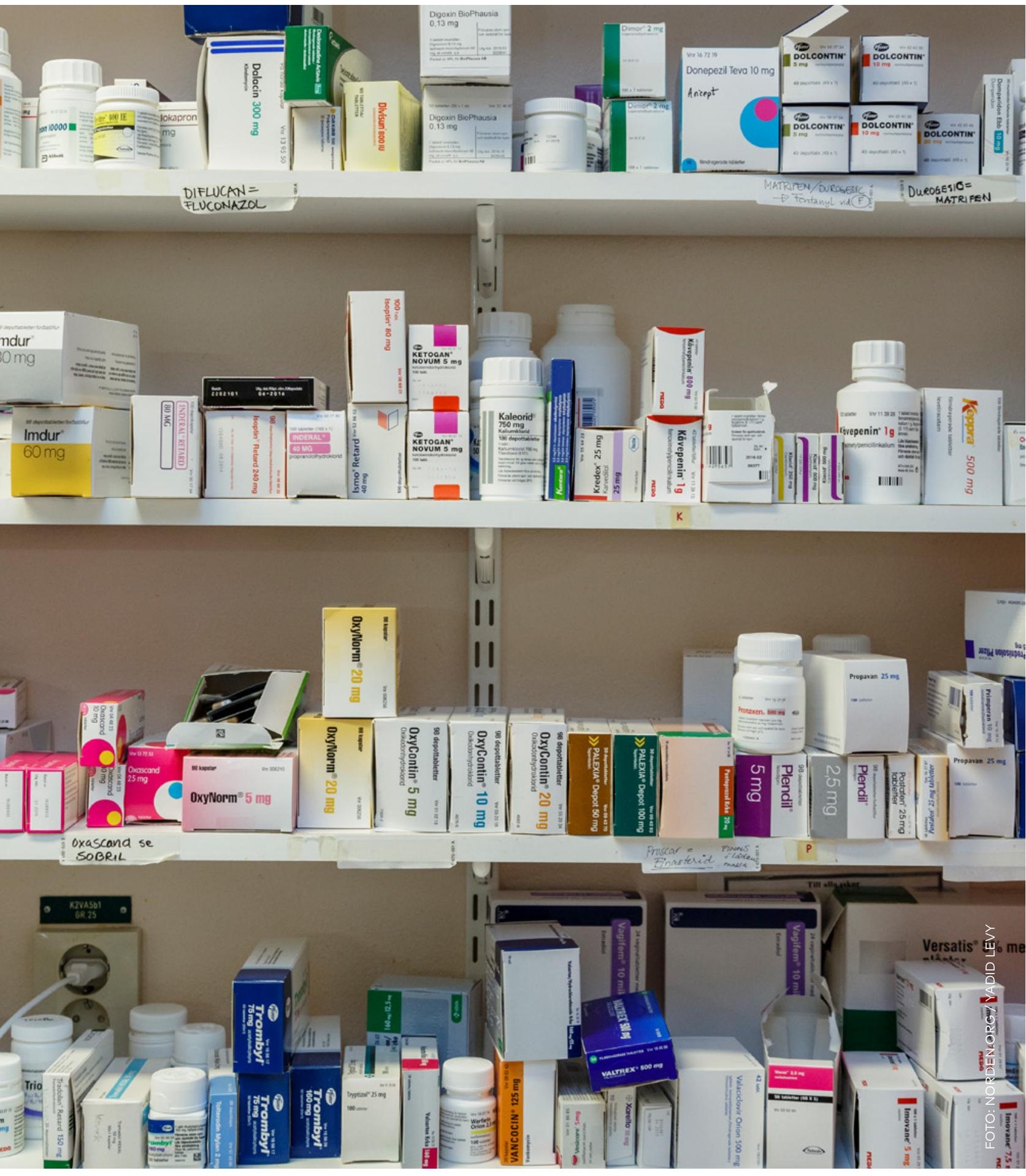




\section{Incitamenter til udvikling af ny antibiotika og vacciner}

Det anbefales, at de nordiske lande samlet efterstræber indførslen af en række økonomiske incitamenter og bedre rammebestemmelser for udviklingen af nye antibiotika og vacciner. For at sikre langsigtede og tilstrækkelige investeringer på området, anbefales det, at indsatsen både sker gennem et fælles nordisk samarbejde og gennem internationale partnerskaber.

Udviklingen og frembringelsen af nye antibiotika er over de seneste årtier aftaget signifikant, næsten til det punkt hvor udviklingen er gået i stå. I dag er der ganske få medicinalvirksomheder, der er aktive i udviklingen af nye antibiotika. Dette kan delvis forklares ud fra to forhold: økonomiske og regulatoriske udfordringer.

For det første lader det til, at private medicinalvirksomheder har vurderet forskningen i nye antibiotika til at være for kostelig ud fra de nuværende markedsvilkår. Nye antibiotika har generelt været dårligt værdisat af tilskudsmyndighederne, i forhold til hvad de kan bidrage til i samfundet. Dette har ført til begrænset udbytte for virksomhederne og dermed også til færre investeringer i forskning og udvikling sammenlignet med andre terapeutiske områder. Med andre ord har udviklingen af nye antibiotika simpelthen ikke været skønnet som økonomisk rentabel.

For det andet har der ikke været et tilstrækkeligt pres og en tilstrækkelig støtte fra politikernes og det offentliges side. Det har været og er en anke fra medicinalindustriens side, at det er for svært at udvikle nye antibiotika pga. de regulatoriske rammers kompleksitet og manglen på økonomiske incitamenter. Myndigheder og politiske beslutningstagere bliver nødt til at sikre bedre rammer for at tilskynde investeringen i nye antibiotika og sikre, at patienter har adgang til dem. 
$\varnothing$ nsker man i de nordiske lande at sikre den fremtidige udvinding af nye generationer af antibiotika og vacciner, er det fuldstændig altafgørende, at man begynder at fokusere på de to ovennævnte forhold og forsøger at fjerne de hindringer og mekanismer, som holder udviklingen af nye produkter og præparater tilbage. Dette kan bl.a. gøres på følgende måder:

- Gensidig forpligtelse fra det offentlige og private medicinalselskaber til at fokusere på udviklingsprogrammer og research.

- Øget fokus på og støtte af offentlig-private samarbejder.

- Øget finansiering og økonomisk støtte til offentlig og privat forskning, der fremmer tilvejebringelsen af ny mikrobiologisk basiskundskab, nye antibiotika og nye vacciner.

- Forbedring af de strukturelle incitamenter og rammebestemmelser for medicinalvirksomheder og forskere til at udvikle ny medicin i form af skattelettelser og økonomisk subsidiering, fx market entry rewards eller lignende.

- Fokus på udvikling af vacciner og forebyggende behandlingspræparater, der tilbyder modstandskraft mod kendte bakterielle- og virusinducerede infektionssygdomme, så anvendelse af antibiotika kan undgås.

- Sikring af produktion af og adgang til ældre antibiotika, som ikke mere produceres af de oprindelige medicinalvirksomheder, men er outsourcet til mindre virksomheder.

- Adressering af udfordringer på tilskudsområdet, som hindrer investering i forskning og udvikling af antibiotika.

- Fokus på innovative incitamenter, der kan accelerere udviklingen af nye antibiotika. 
Skal man imidlertid gøre sig forhåbninger om realiseringen af et mærkbart og væsentligt fremskridt indenfor udviklingen af nye antibiotika, er det som sagt ikke tilstrækkeligt kun at holde sig inden for en nordisk ramme. Af økonomiske og videnskabelige grunde kan Norden ikke løfte opgaven alene. AMR er en global udfordring og bør derfor også håndteres med et globalt perspektiv.

Derfor bør de nordiske lande, i tillæg til indsatsen i nordisk regi, stile efter at etablere og indgå i internationale offentlig-private samarbejder og partnerskaber, som de fx forekommer i USA, Storbritannien eller EU. Partnerskaber, hvor eksperimentelle forsknings- og forsøgsprogrammer til udvikling af ny sundhedsteknologi støttes af offentlige midler frem til det punkt, hvor det vil være økonomisk rentabelt for virksomheder at investere i videreudviklingen og den faktiske produktion af medicin og antibiotika. EU's Innovative Medicines Initiative, New Drugs For Bad Bugs og CARB-X i USA er eksempler på et sådant samarbejde. ${ }^{9}$

Partnerskabsordningen mellem den private og offentlige sektor vurderes fordelagtig, fordi man deler indsatsen og ressourcerne og kombinerer det bedste fra to verdener. Ordningen giver tilmed anpartshaverne en bedre mulighed for at nå til en fælles forståelse samt offentlige interesser en større indflydelse på, hvilke indsatsområder og teknologier der fokuseres på i fremtiden.

9 Blandt andre eksempler bør desuden nævnes Transatlantic Taskforce on Antimicrobial Resistance (TATFAR) samt Joint Programming Initiativ on Antimicrobial Resistance (JPIAMR), der henholdsvis er et samarbejde mellem USA og EU og et internt EU-program. For mere information, se https://www.cdc.gov/drugresistance/tatfar/about.html og http://www.jpiamr.eu/ 


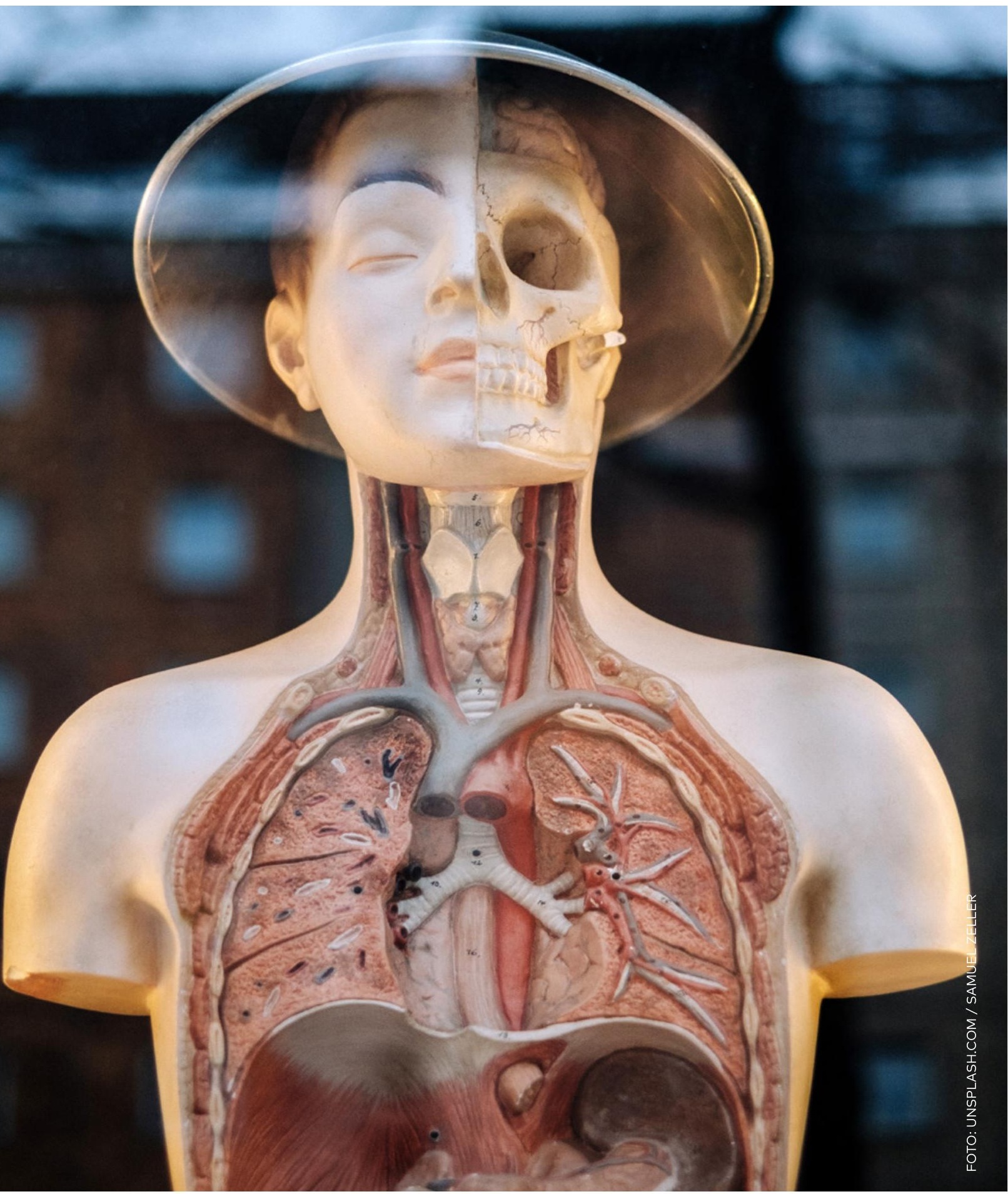




\section{Folkeoplysningskampagner i Norden}

Tilrettelæggelsen af folkeoplysende kampagner, der yderligere kan sprede viden blandt befolkningerne om udfordringerne med antibiotikaresistens, et fornuftigt forbrug af antibiotika og vigtigheden af god hygiejne (både når det gælder dyr, mennesker og miljø), er en væsentlig del af en vellykket strategiplan for bekæmpelsen af AMR.

Siden størstedelen af antibiotikaindtaget blandt mennesker fx ikke foregår på selve sygehusene eller på behandlingsklinikkerne rundt omkring i sundhedssystemet, men derimod ude i de primære sundhedssystemer og blandt befolkningen, er det nødvendigvis her, der bør gøres en ekstraordinær indsats, hvis det overhovedet skal lykkes at mindske det generelle forbrug af antibiotika.

Generelt har de nordiske lande gennem tiden gjort sig gode og vigtige erfaringer, når det kommer til denne indsats, som både kan udbygges og styrkes ved samarbejde.

Udover eventuelle folkeoplysende kampagner foreslås det desuden, at grundlæggende oplysninger og information om AMR og dens bekæmpelse bliver inkluderet $\mathrm{i}$ undervisningsmaterialet i folkeskolerne og i ungdomsuddannelserne i de nordiske lande, samt at undervisning $i$ AMR bliver gjort til en særprioritet på landbrugsuddannelserne og i uddannelsen af læger, tandlæger og dyrelæger. 


\section{Fælles nordisk institut og online-database}

Det anbefales, at der iværksættes tiltag med henblik på at udvikle og oprette et fælles nordisk institut og en online-database på det mikrobiologiske område.

For at styrke forskningen og det vidensgrundlag, som både danner rammerne for de nationale forholdsregler og retningslinjer, hvad angår antibiotikabehandling, vil det være en klart bedre udnyttelse af de nordiske landes ressourcer, hvis der bliver oprettet en fælles onlinedatabase på det mikrobiologiske område samt et fælles nordisk institut eller en samarbejdsorganisation for human og veterinær medicin i Norden. ${ }^{10}$ 
En sådan database og et sådant institut vil nemlig have kapaciteten til at koordinere og understøtte en differentieret indsats både inden for en række prioriterede mikrobiologiske områder, hvor det ikke er muligt i øjeblikket, og inden for områder, som ikke varetages af allerede eksisterende institutioner som fx European Food Safety Authority (EFSA). Dobbeltarbejde bør selvsagt undgås.

Målene med og fordelene ved oprettelsen af databasen og instituttet vil være, at disse to kan varetage følgende opgaver:

- En bedre og hurtigere vidensdeling af data og informationer de nordiske lande imellem, der samtidig skal foregå i realtid (in real time).

- Et øget fokus på specialiseret dataindsamling, når det gælder geografi, behandlingstyper, patientgrupper samt dyrearter og -racer.

- Et øget fokus på hot spot-indsamling.

- Håndtering af pligten for forskellige faggrupper til at indmelde særlig smittefare og resistente bakterier.

- Varetagelse af et udvidet samarbejde og vidensdeling med de baltiske lande.

10 I Norden har man en lang erfaring med sådanne samarbejdsorganisationer. På sundhedsområdet findes eksempelvis Nordisk Odontologisk Institut i Oslo. 


\section{Prioriteret liste over farlige patogener og fælles indkøb af særskilt vigtige antibiotika}

Det anbefales, at der udfærdiges en fælles nordisk liste over både prioriterede farlige patogener, som er vanskelige at behandle, og de særskilt vigtige antibiotika, som skal indkøbes til behandling af infektioner hvor det er tale om antibiotikaresistens.

Bakterier og sygdomme stopper ikke ved landegrænser, men kan sprede sig hurtigt over hele regioner. Derfor er det også nødvendigt, i et koordineret arbejde med bekæmpelsen af AMR, at få udarbejdet en fælles nordisk liste over de særligt farlige patogener, som er resistente overfor de fleste former for antibiotika. ${ }^{11}$ Der findes i forvejen lister over farlige patogener, som udgives af WHO og FAO. ${ }^{12}$ Disse er bestemt brugbare og kan anvendes som grundlag for en nordisk liste, men bør tilpasses Nordens regionale situation og behov.

Samtidig er det afgørende at få klassificeret de særskilt vigtige antibiotika i det nordiske sundhedssystem. Udover tiltag som sikrer rigtig brug af antibiotika, er det nemlig ligeså essentielt at få etableret en stabil tilgængelighed til de antibiotika, som kan anvendes til at behandle sygdomstilfælde med antibiotikaresistens.

Sikker og stabil forsyning til små lægemiddelmarkeder, som de nordiske lande, vil være vigtig. Et af virkemidlerne her vil kunne være at se på nye modeller for indkøb, finansiering og distribution af særskilt vigtige antibiotika.

For at virkeliggøre disse tiltag er det nødvendigt at oprette en samarbejdsorganisation mellem de nordiske lande som forklaret i punkt 8.

11 I nogle nordiske lande, bl.a. Sverige, er en prioriteret liste over farlige patogener lovpligtig.

12 WHO's liste "Critically important antimicrobials for human medicine",

http://www.who.int/foodsafety/publications/antimicrobials-third/en/ 


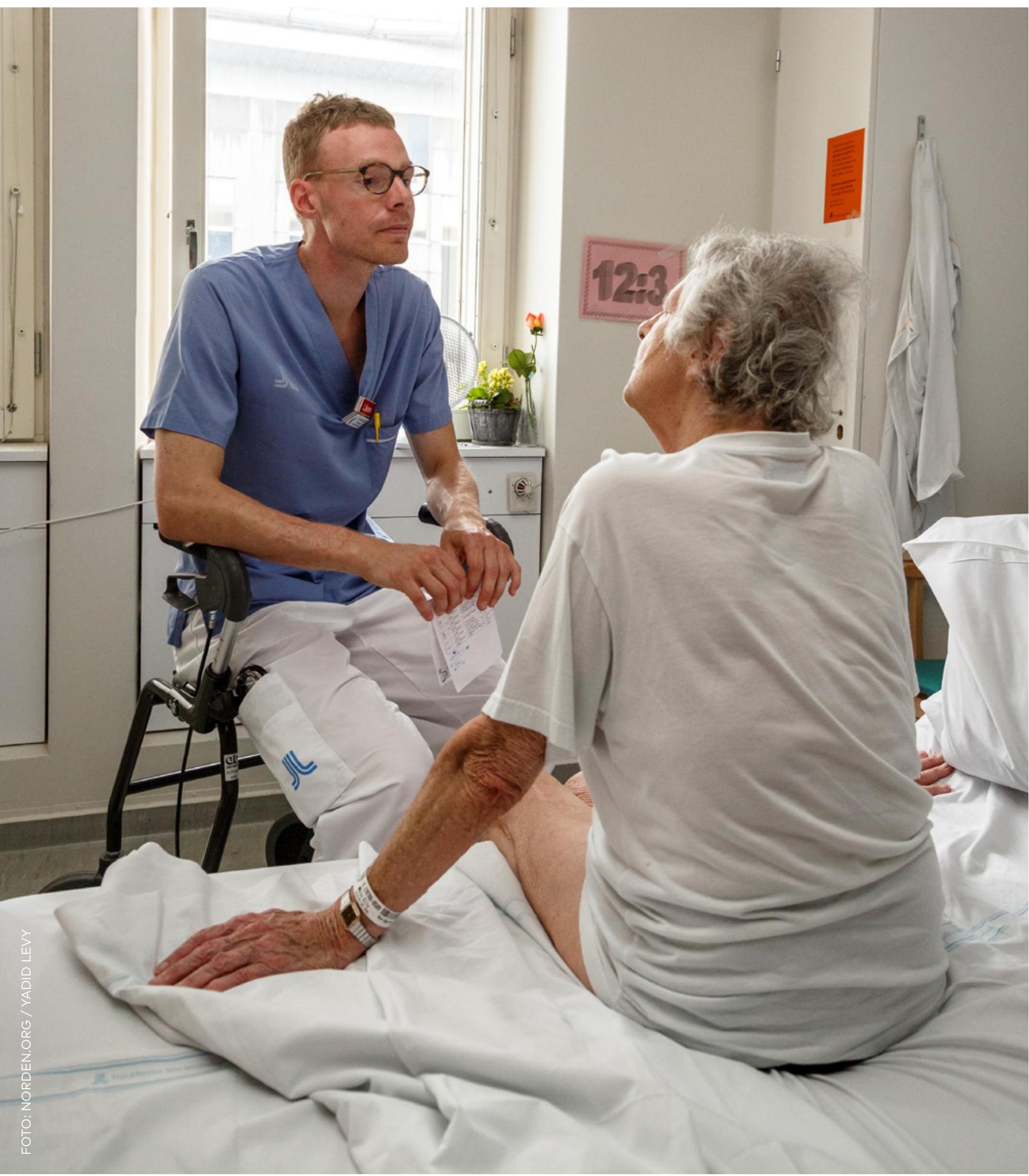




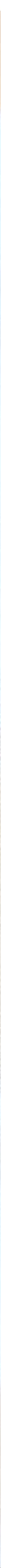




\section{Koordination af fødevarekontrol og arbejds- deling mellem nationale myndigheder i Norden}

Det er et faktum, at reguleringen og håndhævelsen af fødevarekontrol varierer meget mellem de nordiske lande. Danmark har $\mathrm{fx}$ en langt mere restriktiv og omfattende fødevarekontrol end Finland og Island, hvad angår indhold af antibiotika i kød- og andre fødevareprodukter.

En koordination af og overenskomst om fødevarekontrollen mellem de nordiske lande vil nærmest være uundgåelig, såfremt man ønsker en sammenlægning og ensretning af den nordiske indsats mod AMR. En sådan sammenlægning og overenskomst åbner muligheden for en bedre og mere fornuftig udnyttelse af de nationale ressourcer og den ekspertise, som hvert land besidder.

I stedet for at de nordiske landes nationale kontrolmyndigheder og reguleringsinstanser udfører samme arbejde, foreslås det bl.a., at der udformes en bredere arbejdsdeling lande imellem. På den måde spredes arbejdsbyrden og de forskellige overvågningsopgaver ud mellem de nationale institutioner.

Forestillingen er, at fordelingen af arbejdsopgaverne og ansvarsområderne skal foregå efter et erfarings- og ekspertiseprincip. Dette vil betyde, at den myndighed, som ender med at varetage inspektionen, er den myndighed, der har den største erfaring og mest specialiserede ekspertise inden for det pågældende område. Den ansvarshavende institution vil selvfølgelig samtidig være forpligtet til at informere sine søsterorganisationer i de øvige nordiske lande.

Der findes EU-lovgivning på området, hvorfor det selvfølgelig bør undersøges, hvorvidt en koordineret fødevarekontrol ikke er i strid med lovgivningen. 


\section{Norden i Europa og resten af verden}

Det anbefales, at man de nordiske lande imellem kommer til enighed om en samordnet indsats, hvad angår påvirkningen af relevant regulering og lovgivning i EU, og international formidling af nordiske erfaringer med bekæmpelsen af AMR.

I erkendelse af at faren fra AMR ikke blot udgør en regional, men derimod en international trussel mod folkesundheden, er det givet på forhånd, at de nordiske lande selvfølgelig er nødt til at indgå i et bredt politisk samarbejde med andre lande samt delagtiggøre sig i arbejdet inden for internationale sundhedsorganisationer og lignende politiske fora som EU.

Målet med dette samarbejde på tværs af landegrænser må både være at påvirke den internationale lovgivning og regulering på sundhedsområdet samt at formidle de gode nordiske erfaringer med bekæmpelsen af AMR.

Ud fra denne grundpræmis foreslås det, at de nordiske lande som minimum forfølger en koncentreret politisk indsats inden for følgende punkter:

- Udpegning af "best practices" i Norden inden for regulerings- og investeringspolitikken og deres fordele som del af en eksemplarisk strategi, der kan præsenteres for EU, WHO, FAO, OIE, osv.

- Sikring af etiske regler for fremstilling af antibiotika og farmaceutiske produkter.

- Aktiv inddragelse af EU og WHO samt andre relevante internationale fora i de regionale tiltag og omvendt.

- Vedtagelse og koordinering af et fælles nordisk politisk pres på EU, da standardreguleringen af anvendelsen af antibiotika og EU-reglerne for veterinær medicin og dyrevelfærd m.m. også gælder for de nordiske lande. 


\section{Fælles nordisk plan}

Slutteligt anbefales det, at de ovenstående 11 punkter med fordel kan udvikles til en fælles nordisk handlingsplan med finansiering, rapportering og politisk kontrol.

Selvom det måske ikke er muligt at dække alle punkter ind, er det stadig tvingende nødvendigt, at der udarbejdes en fælles nordisk handlingsplan for håndteringen af en eventuel epidemi eller en lignende øjeblikkelig sundhedsmæssig katastrofe, da det utvivlsomt vil styrke det samlede beredskab for de nordiske lande.

Til opbyggelsen af et sådant beredskab kunne man med fordel anvende og aktivere allerede eksisterende nationale programmer og institutioner, som eksempelvis det skandinaviske selskab for infektionsmedicin og klinisk mikrobiologi.

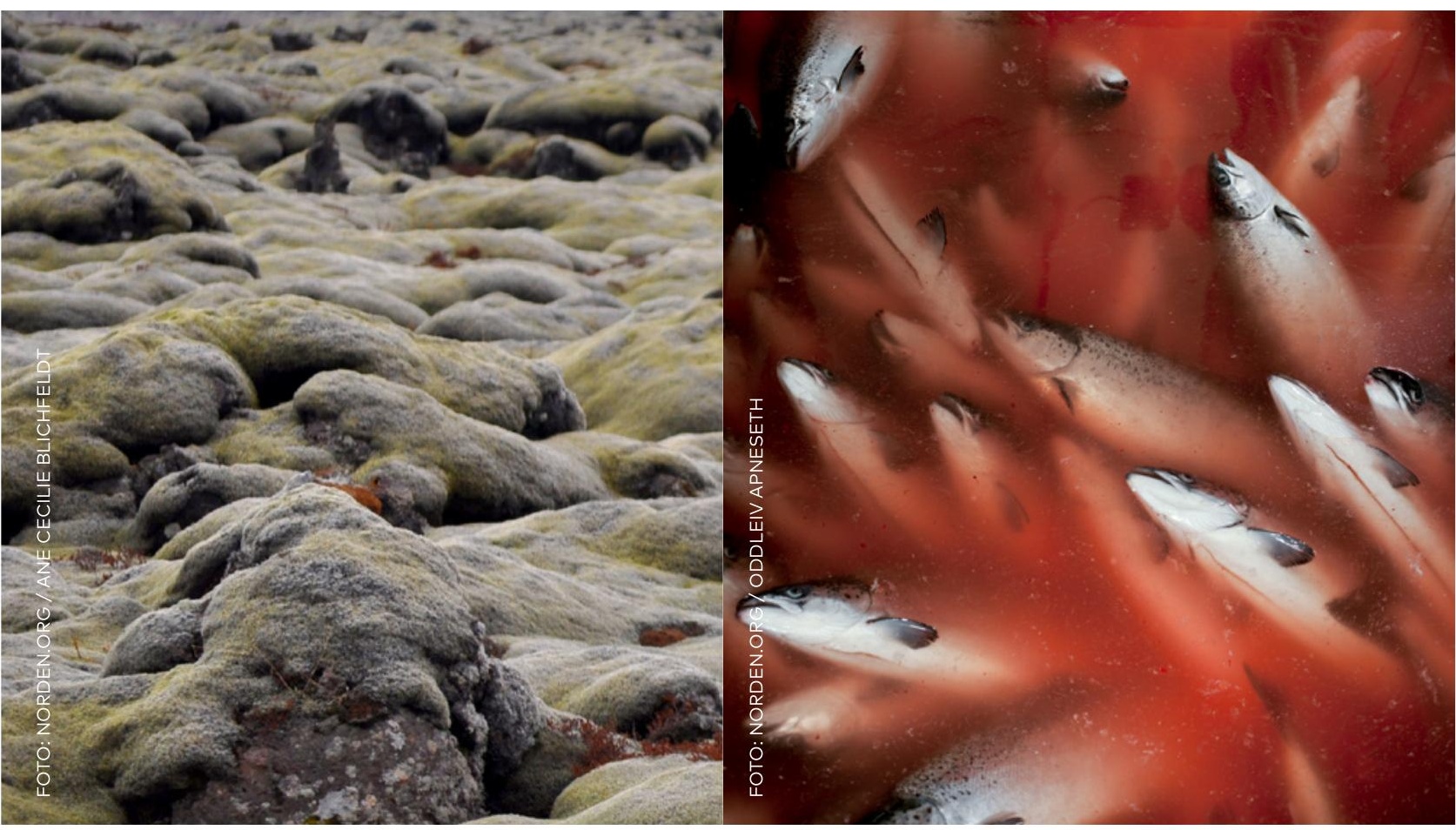




\section{FORKORTELSER}

AMR: Antimikrobiel resistens

EU: Den Europæiske Union

FAO: FN's fødevare- og landbrugsorganisation, The Food and Agriculture Organization

NMR: Nordisk Ministerråd

NR: Nordisk Råd
OIE: Verdensorganisationen for dyrevelfærd og -helse, World Organization for Animal Health

STRAMA: Strategigruppen för rationell antibiotikaanvändning och minskad antibiotikaresistens

WHO: Verdenssundhedsorganisationen, World Health Organization 



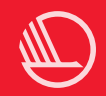

Nordisk Råd

Ved Stranden 18

DK-1061 København K

www.norden.org

ANP 2017:725

ISBN 978-92-893-4946-8 (PRINT)

ISBN 978-92-893-4947-5 (PDF)

ISBN 978-92-893-4948-2 (EPUB) 